\title{
ASSESSMENT OF FINGER MILLET VIRESCENT LINES FOR YIELD AND YIELD RELATED TRAITS USING TOP CROSS METHOD
}

\author{
MANJAPPA $^{1}$, S. RANGAIAH ${ }^{2}$, M. V. C. GOWDA ${ }^{3} \&$ P. RAVISHANKAR ${ }^{4}$ \\ ${ }^{1,2}$ Department of Genetics and Plant Breeding, University of Agricultural Sciences, GKVK, Bengaluru, India \\ ${ }^{3,4}$ Project Coordinating Unit (Small Millet), AICSMIP, GKVK, Bengaluru, India
}

\begin{abstract}
An experiment was conducted to assess nineteen finger millet virescent lines derived from cross [GPU $28 x$ (GE $1 x$ GPU 67)8-5] for seven yield and its attributing traits by following top cross method, where Indaf 9 was used as a tester. The virescent lines along with their top cross progenies and checks (GPU 28, GE 1, GPU 67 and Indaf 9) were evaluated under augmented design. Based on breeding value, per se mean and topcross progeny mean value virescent lines were selected for high grain yield per plant (7-1, 4-1 and 17-6), high fodder weight per plant (12-10, 4-1 and 4-11), more finger numbers per ear head (12-10, 8-3 and 17-6), longer finger length (4-11, 18-2 and 11-6) and reduced flowering time (3-6, 5-2, 8-3, 18-2, 12-4, 4-11, 4-2 and 21-6). Parent-offspring correlation coefficient ( $\left.r_{P o}\right)$ was calculated to ascertain the relationship between parent and offspring, which was found significant for plant height, finger length, finger number, fodder weight per plant and grain yield per plant. Regression of breeding value (A) over phenotypic value $(P)\left(b_{A P}\right)$, which is analogous to heritability was high for finger length $(0.84 \pm 0.1)$, productive tillers $(0.53 \pm 0.1)$ and finger number per ear $(0.5 \pm 0.14)$ and low for fodder weight $(0.03 \pm 2.71)$ and grain yield $(0.09 \pm 0.7)$.

KEY WORDS: Finger Millet, Virescent Lines, Breeding Values, Topcross \& Tester
\end{abstract}

Received: May 16, 2017; Accepted: Jun 17, 2017; Published: Jun 21, 2017; Paper Id.: IJASRAUG20171

\section{INTRODUCTION}

Cultivated finger millet (Eleusine coracana subsp. coracana) is an allotetraploid $(2 \mathrm{n}=4 \mathrm{x}=36)$ nutri-cereal crop and it belongs to the Poaceae family and Chloridoideae sub-family (Srinivasachary et al., 2007). It is adapted to a wide range of agro-climatic conditions and provides critical plant genetic resources upon which millions depend for food and rural household incomes on infertile and marginal lands (Hilu et al., 1979). Finger millet is known for its excellent nutritional value having high protein, methionine and other essential amino acids. It also has some medicinal properties viz., hypoglycemic, hypocholestromic and is rich in antioxidants, hence highly valued for diabetics and for better gastrointestinal health (Devi et al., 2011). It is also known as a food security crop in the times of famine due to its excellent storage quality, where small seeds can be stored for years without damage from storage insects (Dida et al., 2007).

Over the last two decades, area and production of finger millet are in declining phase due to the replacement of this crop by other competitive crops, so there is a need to increase its productivity. To achieve this, efforts have been made in realizing high yield potential using genetic resources across the world. Improved finger millet varieties have been developed mostly by selection or hybridization followed by selection. Such varieties have a maximum yield potential of 50-55 q/ha (Gowda, 2014), but it is almost reaching stagnation. To achieve higher yield potential, release of maximum variability is essential, but in finger millet this release of variability is 
slow and arduous because of its polyploid nature and difficulty in hybridization. Polyploidy nature of crop demands greater shuffling of genes for reaching higher genetic potential, which can be achieved by using recurrent selection method.

In finger millet crossing program, emasculation is very difficult due to its small florets. However, some of the crossing methods viz., hot water method, polybag method, use of gametocides and contact method have been followed. In the absence of robust morphological marker in parent's identification of $F_{1}$ 's is very difficult. Utility of molecular marker in testing hybridity is not practicable because of low recovery of hybrids. The use of robust phenotypic markers in crossing program to identify hybrids can enhance recombination breeding. Virescence marker is one of that kind, which expresses stably during the seedling stage and helps to identify $\mathrm{F}_{1} \mathrm{~s}$ at seedling stage itself.

In finger millet breeding programs, genotypes are selected based on their per se phenotypic performance. Here a direct phenotypic selection could mislead breeder in selecting desirable genotype as quantitative characters exhibit low heritability. One of the most efficient procedures for identifying genotypes with potential use of artificial crosses is the top cross, where selection is performed based on breeding value. This procedure precisely and rapidly tests large number of lines (pure lines, open pollinated and synthetic populations) with common genotype having wide genetic background, known as tester. It was first proposed by Jenkin and Brunsen (1932), as a method of testing inbred lines of maize in crossbred combinations. Later, Tysdal and Grandall (1948) renamed it as top cross. Two important aspects of topcross method are assessing parents in pairwise combination: i) the contribution of each parent is directly transferred to the progeny main,

(XParents $\mathrm{x} \bar{X}_{\text {Progenies }}$ ), i.e. Through additive gene action, and ii) the reliability of the results being obtained is independent of the quantitative or qualitative nature of the data. Topcross method was used in the assessment of maize parental lines by several workers (Keller, 1949; Horner et al., 1976; Gama et al., 1993; Sawazaki et al., 2000; Duarte et al., 2003; Mihaljevic et al., 2005). In the present study, nineteen virescent lines have been assessed based on their topcross progeny performance and superior lines are selected based on their breeding value.

\section{MATERIAL AND METHODS}

The experiment was carried out in Project Coordinating Unit (Small millets), AICSMIP, GKVK, Bengaluru, India during kharif season 2014.

Nineteen phenotypically superior virescent lines (expresses yellow leaf color during seedling stage) was selected in the $\mathrm{F}_{3}$ generation of the cross [GPU $28 \times$ (GE 1 x GPU 67)8-5)] involving superior parental lines. The performance of virescent lines was assessed for seven yield and yield attributing traits by following topcross method. Indaf 9, a tall, vigorous and pigmented variety was used as a tester, which was found to have a good general combining ability (Krishnappa et al., 2009). This tester was crossed with 19 virescent lines to develop topcross progenies. Since virescence (yellow leaf color) is recessive to green leaf color, virescent lines were used as female parents to facilitate easier identification of $F_{1 s}$ (green) at seedling stage. Virescent lines and their corresponding topcross progenies (green $F_{1}$ seedlings) along with four checks viz., GPU 28, GE 1, GPU 67 and Indaf 9 were transplanted from the nursery to field and evaluated under augmented design in two blocks. The breeding values of virescent lines were estimated using adjusted means of parents and corresponding top cross progenies (Jenkins and Brunsen, 1932). Based on breeding value, per se means and top cross progeny mean values superior virescent lines were selected. 


\section{STATISTICAL METHODS}

\section{Breeding Value of Parents (A)}

The breeding value is the standardized deviation of progeny means from the general mean of all progenies developed in a crossbreeding program. Breeding value represents gca effect (fixable component) of individual parent.

$$
\mathrm{A}_{\mathrm{i}}=\mathrm{A}_{\mathrm{i}}{ }^{\prime} /\left(\mathrm{SD}\left(\mathrm{A}_{\mathrm{i}}{ }^{\prime}\right)=\left(\overline{\mathbf{c}}_{\mathrm{i}^{-}} \overline{\mathbf{c}}\right) /\left(\mathrm{SD}\left(\mathrm{A}_{\mathrm{i}}{ }^{\prime}\right)\right.\right.
$$

Where,

$\mathrm{A}_{\mathrm{i}}=\quad$ standardized breeding value of $\mathrm{i}^{\text {th }}$ parent

$\mathrm{A}_{\mathrm{i}}{ }^{\prime}=\quad$ unstandardized breeding value: deviation of progeny mean from the overall mean of progenies $(0)$, such that sum of all $\mathrm{A}_{\mathrm{i}}{ }^{\prime}=0$

\section{Parent-Offspring Correlation $\left(\boldsymbol{R}_{o p}\right)$}

Significance of breeding value in the parent was judged based on parent-progeny correlation (rop); where parent (p) was an independent variable and the offspring (o) was dependent variable for any character, as

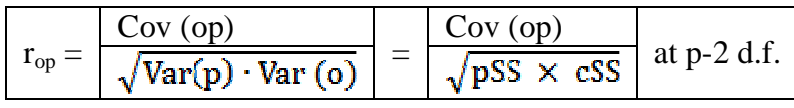

Where,

pSS and cSS are obtained from ANOVA table

\section{Parent-Offspring Regression $\left(B_{o p}\right)$}

$$
\begin{array}{|l|l|}
\hline b_{\mathrm{op}}= & \operatorname{Cov}(\mathrm{op}) \\
\cline { 2 - 3 } & \mathrm{pSS} \\
\hline
\end{array}
$$

Regression of Breeding Value (A) on Phenotypic Value $\left(b_{A P}\right)$

$b_{A P}$ is analogous to heritability.

Where,

$$
\begin{array}{|l|l|}
\hline \multirow{2}{*}{\mathrm{b}_{\mathrm{AP}}=} & \operatorname{Cov}(\mathrm{AP}) \\
\cline { 2 - 2 } & \operatorname{Var}(\mathrm{P}) \\
\hline
\end{array}
$$

$$
\begin{aligned}
& \operatorname{Cov}(\mathrm{AP})=\Sigma_{\mathrm{i}}^{\mathrm{p}} \mathrm{Ai} \times \overline{\mathrm{P}}_{\mathrm{i}}=\mathrm{A}_{1} \mathbf{x} \overline{\mathrm{\Gamma}}_{1}+\mathrm{A}_{1} \mathbf{x} \overline{\mathrm{\Gamma}}_{2}+\ldots \ldots \ldots \mathrm{A}_{\mathrm{n}} \mathbf{x} \overline{\mathrm{\Gamma}}_{\mathrm{n}} \\
& \operatorname{Var}(\mathrm{P})=\Sigma_{\mathrm{i}}^{\mathrm{P}} \overline{\mathrm{P}}_{\mathrm{i}}^{2}-(\Sigma \mathrm{P} \mathbf{i})^{2} / \mathrm{P} \\
& \operatorname{SE}\left(\mathrm{b}_{\mathrm{AP}}\right)=\left[\frac{\operatorname{Cov}(\mathrm{AP})^{2}}{\operatorname{Var}(\mathrm{P})} /(\mathrm{p}-2) \operatorname{Var}(\mathrm{A})\right]
\end{aligned}
$$

\section{RESULTS AND DISCUSSIONS}

During Kharif 2014, nineteen virescent lines, their corresponding top crosses and checks were evaluated under augmented design. Analysis of variance revealed significant differences among test entries for all the traits except productive tillers per plant and plant height (Table 1). Significant differences were also observed among the checks for all 
traits except productive tillers per plant.

Breeding value (A) is the main parameter in selection of lines, though topcross analysis (Jenkin and Brunsen, 1932) as it represents the $g c a$ (general combining ability) effect of the individual test line. Larger the A, the greater is the gca effect (fixable component). The genetic background of the tester (Indaf 9) is common to all nineteen test-virescent lines; i.e. contribution of pollen parent (tester) is same to all hybrid progenies (topcrosses). Therefore, should there be any significant difference between half-sib families (topcrosses), it must be necessarily due to differential ability of test virescent lines to contribute differentially to the progenies. Hence, the superiority of a half-sib family (topcross progeny) is attributed to the superior combining ability (breeding value) of respective virescent lines.

In this study superior virescent lines having high breeding value along with high per se mean and high topcross progeny mean were selected. For days to flowering, virescent lines having low per se mean and low topcross progeny mean is selected (Table 2). Superior virescent lines are tabulated in Table 2 with their breeding value, per se mean value and their topcross mean value for different yield and its related traits. For grain yield per plant, 7-1, 4-1 and 17-6 lines were found to be superior, with high 'A' of 1.46, 1.35 and 1.01 with per se mean of 16.78, 15.18 and $20.18 \mathrm{~g}$ and its top cross progeny mean of $22.08 \mathrm{~g}, 21.53 \mathrm{~g}$ and $19.83 \mathrm{~g}$ respectively. For days to flowering, 3-6,5-2, 8-3, 18-2, 12-4, 4-11, 4-2 and 21-6 lines were selected based on their highest negative breeding value (-0.73) with low per se mean and low topcross mean (Table 2), because early flowering is a desirable trait. For fodder weight, 12-10, 4-1 and 4-11 lines having high 'A' among virescent lines with high per se mean of $85.23 \mathrm{~g}, 55.83 \mathrm{~g}$ and $37.23 \mathrm{~g}$ with their top cross mean of $95.38 \mathrm{~g}, 90.28 \mathrm{~g}$ and $82.38 \mathrm{~g}$ respectively were selected. Likewise for finger length 4-11, 18-2 and 11-6 and for finger number per ear head 12-10, 8-3 and 17-6 virescent lines were selected. Virescent line 4-1 has shown high 'A' for both grain yield and fodder weight and 12-10 shown high ' $\mathrm{A}$ ' for both finger number and fodder weight. These selected virescent lines could be explored in the hybridization breeding program for yield improvement in finger millet.

Parent-offspring correlation coefficient was calculated to ascertain the relationship between parent and offspring. Significant parent-offspring correlation was observed for plant height, finger length, finger number, fodder weight and grain yield (Table 3). This indicates the authentic nature of breeding values computed for these traits. Therefore, selection of parents could be made based on the breeding value of these traits.

However, other genetic parameter, regression of breeding value $(\mathrm{A})$ over phenotypic value $(\mathrm{P})\left(\mathrm{b}_{\mathrm{AP}}\right)$ which is analogous to heritability is also an important criteria to select parents based on per se mean. Among the traits under study, finger length $(0.84 \pm 0.1)$, productive tillers $(0.53 \pm 0.1)$ and finger number per ear $(0.5 \pm 0.14)$ had highest heritability. Fodder weight $(0.03 \pm 2.71)$ and grain yield $(0.09 \pm 0.7)$ have shown low heritability compared to other traits (Table 3$)$, which can be due to the complexity of the traits and are greatly influenced by environment. Thus lines selected based on their breeding value, per se mean and topcross progeny mean value would be a good resource for recombination breeding in finger millet

\section{CONCLUSIONS}

Thus lines selected for grain yield viz., 7-1, 4-1 and 17-6 and yield related traits based on their breeding value, per se mean and topcross progeny mean value would be good resource for recombination breeding in finger millet. 


\section{ACKNOWLEDGEMENTS}

University Grant Commission is acknowledged for the award of Junior Research Fellowship for Ph. D research programme. Project Coordinating Unit (Small Millets), AICSMIP, GKVK, Bengaluru is greatly acknowledged for providing all the facility and material for conducting this research work.

\section{REFERENCES}

1. Devi, P.B., Vijayabharathi, R., Sathyabama, S., Malleshi, N.G. and Priyadarisini, V.B., 2011. Health benefits of finger millet (Eleusine coracana L.) polyphenols and dietary fiber: a review. J. Food Sci. Technol., doi10.1007/s13197-011-0584-9.

2. Dida, M.M., Srinivasachary Ramakrishna S., Bennetzen, J.L., Gale, M.D. and Devos, K.M., 2007. The genetic map of finger millet, Eleusine coracana. Theor. Appl. Genet. 114, 321-2. http://dx.doi.org/10.1007/s00122-006-0435-7

3. Duarte, I.A., Ferreira, J.M. and Nuss, F.C.N., 2003. Screening potential of three maize topcross testers (in Portuguese; English summary). Pesqui. Agropec. Bras. 38: 365-372.

4. Gama, E.E., Magnavaca, G.R., Parentoni, S.N., Pacheco, C.A.P., Guimarães, P.E.O. and Oliveira, A.C. 1993. Evaluation of maize (Zea mays L.) top crosses for their potential use in a breeding program. Pesqui. Agropec. Bras. 28: 481-487.

5. Gowda, M. V. C., Nanja Reddy, Pushpalatha, N., Deepika, M., Pramila, C. K. and Sachin, S. J., 2014. Compendium of varieties in small millets. Project coordinating unit, All India Coordinated Small Millets Improvement Project, Indian Council of Agriculture Research, GKVK, Bengaluru.

6. Hilu, K.W., De Wet, J.M.J. and Harlan, J.R., 1979. Archaeobotanical studies of Eleusine coracana ssp. coracana (finger millet). Am. J. Bot. 66: 330-3. http://dx.doi.org/10.2307/2442610

7. Horner, E.S., Lutrick, M.C., Chapman, W.H. and Martins, F.G., 1976. Effect of recurrent selection for combining ability with a single cross tester in maize. Crop Sci. 16: 5-8.

8. Jenkins, M. T. and Brunsen, A. M., 1932. Methods of testing inbred lines of Maize in cross bred combinations. J. Amer. Soc. Agron., 24: 523-530.

9. Keller, K.F., 1949. A comparison involving the number of, and relationship between, testers in evaluating inbred lines of maize. Agron. J. 41: 323-331.

10. Krishnappa, M., Ramesh, S., Chandraprakash, J., Jayarame Gowda, Bharathi and Dayal Doss, D., 2009. Breeding potential of selected crosses for genetic improvement of finger millet. An Open Access Journal published by ICRISAT. 7: 1-6.

11. Mihaljevic, R., Schon, C.C., Utz, F. and Melchinger, A.E., 2005. Correlations and QTL correspondence between line per se and testcross performance for agronomic traits in four populations of European maize. Crop Sci. 45: 114-122.

12. Sawazaki, E., Paterniani, MEAGZ, Castro, J.L., Gallo, P.B., Galvão, J.C.C. and Saes, L.A., 2000. Inbred line potentials for the synthesis of new popcorn hybrids (in Portuguese; English summary). Bragantia, 59: 143-151.

13. Srinivasachary, Dida, M.M., Gale, M.D. and Devos, K.M., 2007. Comparative analyses reveal high levels of conserved collinearity between the finger millet and rice genomes. Theor. Appl. Genet., 115: 489-499.

14. Tysdal, H. M. and Grandall, B. M., 1948. The poly cross progeny performance as an index of the combining ability of alfalfa clones. J. American Soc. Agron., 40: 293-306. 


\section{APPENDICES}

Table 1: Analysis of Variance of Nineteen Virescent Genotypes and their Corresponding

Top Crosses for Yield and its Attributing Traits

\begin{tabular}{|l|c|c|c|c|c|c|c|c|}
\hline Source of Variation & d.f. & DF & PT & PHT & FL & FN & FOW & YLD \\
\hline Block & 1 & 0 & 0.1 & 0.9 & 0.07 & 0.32 & $0.2^{*}$ & 0.2 \\
\hline Entries & 41 & $15.3^{* * *}$ & 0.4 & $124.9^{*}$ & $0.72^{* *}$ & $0.67^{*}$ & $415.9^{* * *}$ & $22.6^{*}$ \\
\hline Checks & 3 & $76^{* * *}$ & 0.2 & $274.3^{*}$ & $4.59^{* * *}$ & $3.66^{* *}$ & $582.5^{* * *}$ & $41.1^{* *}$ \\
\hline Genotypes & 37 & $10.4^{* * *}$ & 0.4 & 92.2 & $0.41^{*}$ & $0.44^{*}$ & $387.1^{* * *}$ & $20^{*}$ \\
\hline Checks $v s$ Genotypes & 1 & $15.9^{* * *}$ & 0.2 & $887.8^{* *}$ & $0.39^{*}$ & 0.04 & $981.3^{* * *}$ & $61^{*}$ \\
\hline Error & 3 & 0 & 0.1 & 11.3 & 0.02 & 0.04 & 0 & 1.4 \\
\hline
\end{tabular}

Abbreviations: d.f., degrees of freedom; DF, days to $50 \%$ flowering; PT, productive tiller number per plant; PHT, plant height $(\mathrm{cm})$; FL, finger length $(\mathrm{cm})$; FN, finger number per ear; FOW, fodder weight per plant (g); YLD, grain yield per plant.

Table 2: Breeding Values of Virescent Genotypes along with their Per Se Mean and Top Cross Progeny Mean

\begin{tabular}{|c|c|c|c|c|c|c|c|c|c|c|c|c|c|c|c|c|}
\hline \multirow[b]{2}{*}{ Sl. No. } & \multirow[b]{2}{*}{$\begin{array}{l}\text { Virescent } \\
\text { lines }\end{array}$} & \multicolumn{3}{|c|}{ Days To 50\% Flowrering } & \multicolumn{3}{|c|}{ Finger Length $(\mathrm{Cm})$} & \multicolumn{3}{|c|}{ Number Of FingersEar Head } & \multicolumn{3}{|c|}{ Fodder Weight Plant (G) } & \multicolumn{3}{|c|}{ Grain YieldPlant (G) } \\
\hline & & $\begin{array}{l}\text { Breeding } \\
\text { Value }\end{array}$ & $\begin{array}{l}\text { Per Se } \\
\text { Mean }\end{array}$ & \begin{tabular}{|c|} 
Topeross \\
Progeny \\
Mean \\
\end{tabular} & $\begin{array}{l}\text { Breeding } \\
\text { Value }\end{array}$ & $\begin{array}{l}\text { Per Se } \\
\text { Mean }\end{array}$ & \begin{tabular}{c|} 
Topcross \\
Progeny \\
Mean \\
\end{tabular} & $\begin{array}{l}\text { Breeding } \\
\text { Value }\end{array}$ & $\begin{array}{l}\text { PerSe } \\
\text { Mean } \\
\end{array}$ & \begin{tabular}{|c} 
Topcross \\
Progeny \\
Mean \\
\end{tabular} & $\begin{array}{c}\text { Breeding } \\
\text { Value }\end{array}$ & $\begin{array}{l}\text { PerSe } \\
\text { Mean }\end{array}$ & \begin{tabular}{|c|} 
Topcross \\
Progeny \\
Mean \\
\end{tabular} & $\begin{array}{c}\text { Breeding } \\
\text { Value }\end{array}$ & $\begin{array}{l}\text { Per Se } \\
\text { Mean }\end{array}$ & $\begin{array}{c}\text { Topcross } \\
\text { Progeny Mean } \\
\text { Pan }\end{array}$ \\
\hline 1 & $8-12$ & -0.13 & 85 & 79 & 0.06 & 5.91 & 7.19 & 0.53 & 9.6 & 8.6 & -0.21 & 63.83 & 59.98 & -1.66 & 11.38 & 6.43 \\
\hline 2 & 3.6 & -0.73 & 86 & 78 & -0.87 & 5.66 & 6.79 & 0.16 & 8.3 & 8.4 & -0.49 & 40.33 & 54.78 & -0.79 & 14.43 & 10.83 \\
\hline 3 & $4 \cdot 1$ & 1.08 & 87 & 81 & 0.06 & 5.53 & 7.19 & 0.53 & 8.8 & 8.6 & 1.47 & 55.83 & 90.28 & 1.35 & 15.18 & 21.53 \\
\hline 4 & $9-2$ & 0.48 & 81 & 80 & -1.33 & 5.81 & 6.59 & -0.21 & 8 & 8.2 & -0.05 & 83.43 & 62.88 & -1.32 & 18.18 & 8.13 \\
\hline 5 & 3.3 & 0.48 & 81 & 80 & -0.17 & 5.91 & 7.09 & -1.14 & 8 & 7.7 & -0.32 & 31.43 & 57.98 & 1.01 & 10.98 & 19.83 \\
\hline 6 & $1-4$ & 2.90 & 87 & 84 & -1.33 & 6.11 & 6.59 & -0.21 & 7.4 & 8.2 & 0.48 & \begin{tabular}{|l}
33.63 \\
\end{tabular} & 72.43 & 0.96 & 14.38 & 19.58 \\
\hline 7 & 5.2 & -0.73 & 83 & 78 & 0.29 & 5.81 & 7.29 & 0.53 & 9 & 8.6 & 0.34 & 22.83 & 69.78 & -0.83 & 8.18 & 10.63 \\
\hline 8 & 8.3 & -0.73 & 85 & 78 & -0.75 & 6.11 & 6.84 & 1.64 & 7.8 & 9.2 & 0.84 & 32.03 & 78.93 & 0.36 & 10.78 & 16.58 \\
\hline 9 & $88-2$ & -0.73 & 86 & 78 & 1.68 & 7.61 & 7.89 & -0.96 & 8.2 & 7.8 & -0.55 & 39.03 & 53.78 & -1.14 & 15.78 & 9.03 \\
\hline 10 & $2 \cdot 10$ & -0.13 & 87 & 79 & 0.75 & 5.71 & 7.49 & 1.64 & 8.8 & 9.2 & 1.75 & \begin{tabular}{|l|}
85.23 \\
\end{tabular} & 95.38 & -0.35 & 14.58 & 13.03 \\
\hline 11 & 7.1 & 0.48 & 87 & 80 & 0.59 & 6.01 & 7.42 & -0.21 & 8.2 & 8.2 & 0.32 & 41.83 & 69.43 & 1.46 & 16.78 & 22.08 \\
\hline 12 & 22.4 & -0.73 & 81 & 78 & -0.41 & 6.11 & 6.99 & 0.53 & 7 & 8.6 & 0.26 & 54.83 & 68.38 & 1.09 & 13.98 & 20.23 \\
\hline 13 & 1.2 & 0.48 & 81 & 80 & -0.75 & 6.41 & 6.84 & 0.71 & 8.2 & 8.7 & 0.33 & 59.63 & 69.68 & 0.81 & 19.18 & 18.83 \\
\hline 14 & 411 & -0.73 & 80 & 78 & 2.38 & 6.61 & 8.19 & -0.96 & 9.2 & 7.8 & 1.03 & 37.23 & 82.38 & -0.31 & 9.38 & 13.23 \\
\hline 15 & 11.6 & -1.34 & 82 & 77 & 1.22 & 6.31 & 7.69 & -0.96 & 8.4 & 7.8 & -1.22 & 44.43 & 41.58 & -0.11 & 7.98 & 14.23 \\
\hline 16 & $4 \cdot 2$ & -0.73 & 81 & 78 & -1.10 & 5.91 & 6.69 & 0.16 & 7.4 & 8.4 & -0.19 & 45.83 & 60.18 & -0.59 & 12.78 & 11.83 \\
\hline 17 & 11.6 & -0.73 & 82 & 78 & 0.06 & 5.71 & 7.19 & -0.21 & 6.8 & 8.2 & 0.16 & 28.43 & 66.58 & 0.25 & 11.18 & 16.03 \\
\hline 18 & 776 & 0.48 & 85 & 80 & 0.06 & 5.81 & 7.19 & 0.90 & 8.4 & 8.8 & -1.58 & 53.63 & 35.18 & 1.01 & 20.18 & 19.83 \\
\hline 19 & $2 \cdot 1$ & 1.08 & 87 & 81 & -0.41 & 6.11 & 6.99 & -2.44 & 7 & 7 & -2.37 & 25.83 & 20.78 & -1.18 & 7.58 & 8.83 \\
\hline
\end{tabular}

Table 3: Genetic Parameters Representing Parent-Offspring Relationship of Nineteen Virescent Lines and its Topcrosses

\begin{tabular}{|l|c|c|c|c|c|c|c|}
\hline Genetic Parameter & DF & PT & PHT & FL & FN & FOW & YLD \\
\hline $\mathrm{r}_{\mathrm{OP}}$ & 0.335 & 0.310 & $0.811^{* *}$ & $0.563 * * *$ & $0.433 *$ & $0.562 * * *$ & $0.377 *$ \\
\hline $\mathrm{b}_{\mathrm{OP}}$ & 0.264 & 0.518 & 0.796 & 0.540 & 0.465 & 0.692 & 0.431 \\
\hline $\mathrm{b}_{\mathrm{AP}}$ & 0.139 & 0.532 & 0.056 & 0.836 & 0.498 & 0.031 & 0.089 \\
\hline $\mathrm{SE}\left(\mathrm{b}_{\mathrm{AP}}\right)$ & 0.408 & 0.100 & 1.533 & 0.100 & 0.141 & 2.705 & 0.701 \\
\hline
\end{tabular}

$*, * * *$ significant at 0.05 and 0.001 level.

Abbreviations: DF, days to 50 \% flowering; PT, productive tiller number per plant; PHT, plant height (cm); FL, finger length $(\mathrm{cm})$; FN, finger number per ear; FOW, fodder weight per plant (g); YLD, grain yield per plant. 